$\begin{array}{ll}\text { Abstracta Iranica } & \begin{array}{l}\text { Abstracta Iranica } \\ \text { Revue bibliographique pour le domaine irano-aryen }\end{array} \\ & \text { Volume } \mathbf{2 4} \text { | } \mathbf{2 0 0 3} \\ \text { Comptes rendus des publications de } \mathbf{2 0 0 1}\end{array}$

\title{
« Use of Water in Phoenician Sanctuaries ». ANES $38,(2001)$, pp. 139-159.
}

\section{Astrid Nunn}

\section{(2) OpenEdition}

1 Journals

Édition électronique

URL : http://journals.openedition.org/abstractairanica/34296

DOI : 10.4000/abstractairanica.34296

ISSN : 1961-960X

Éditeur :

CNRS (UMR 7528 Mondes iraniens et indiens), Éditions de l'IFRI

\section{Édition imprimée}

Date de publication : 15 mai 2003

ISSN : 0240-8910

\section{Référence électronique}

Astrid Nunn, « « Use of Water in Phoenician Sanctuaries ». ANES 38, (2001), pp. 139-159. », Abstracta Iranica [En ligne], Volume 24 | 2003, document 62, mis en ligne le 05 janvier 2010, consulté le 25

septembre 2020. URL : http://journals.openedition.org/abstractairanica/34296 ; DOI : https://doi.org/ 10.4000/abstractairanica.34296

Ce document a été généré automatiquement le 25 septembre 2020.

Tous droits réservés 


\section{«Use of Water in Phoenician Sanctuaries ». ANES 38, (2001), pp. 139-159.}

\section{Astrid Nunn}

1 L'importance de l'eau dans les sanctuaires phéniciens est évidente puisque nulle part ailleurs au Levant il n'existe d'installations aussi grandes et variées qu'à Amrit ou Sidon/Bostan aš-ŠayḦ, pour ne citer que les deux exemples les plus grandioses de l'époque achéménide. Le thème de l'eau a ainsi toujours été abordé, mais de manière trop superficielle au goût de l'auteur. C'est pourquoi elle nous livre ici une synthèse sur les différents types d'acheminement d'eau, qu'il s'agissent de pièces d'eau, bassins réguliers, baignoires, citernes, canaux ou puits. Le sanctuaire le plus ancien est celui de Baalat dans le Byblos du Bronze Ancien, les dispositions les plus récentes sont hellénistiques. Il y a eau et eau : certaines installations semblent avoir été d'ordre plus pratique, d'autres évidemment d'ordre cultuel et purificateur. L'eau en bassin jouait un rôle très important dans les temples dédiés aux dieux guérisseurs Emun et Astarte. Les cuves au contraire, étaient plutôt associées à Anat et Astarte.

\section{INDEX}

Thèmes : 3.2.2. Pré-Achéménides et Achéménides 
AUTEURS

ASTRID NUNN

Université de Munich 